\title{
Enzymatic Degradation of Fatty Acid Hydroperoxides Produced in Cowpea and Cucumber Leaves Infected with Cucumber Mosaic Virus*
}

\author{
Sakari KATO** \\ 加藤 盛**：CMV に感染したササゲおよびキュウリ葉内に生成される脂質過酸化物の酵素的分解
}

\begin{abstract}
The subcellular localization of fatty acid hydroperoxide cleavage enzyme in cowpea and cucumber leaves and the changes of its activity by CMV-infection were studied. Most of the enzyme activities in the leaf tissue were mainly located in plasma membrane. Little activity was associated with endoplasmic reticulum, mitochondria and microbody. The enzyme activity and malonaldehyde content in cowpea, local lesion host of CMV, increased rapidly during $12 \mathrm{hr}$ after inoculation and then decreased gradually as lesion appeared. However, the enzyme activity and malonaldehyde content did not change significantly in cucumber over a period of 10 days after inoculation.
\end{abstract}

(Received October 23, 1979)

\section{Introduction}

Previous works in our laboratory demonstrated that the hypersensitive death of cowpea cells infected with cucumber mosaic virus (CMV) was caused by oxidation products formed by the peroxidatoin of unsaturated fatty acids of membranes ${ }^{6,8)}$. The cytotoxic action of lipid hydroperoxides was due to the strong oxidative action of the peroxy-structure. The peroxidation of unsaturated fatty acids is an usual phenomenon in the healthy plants, but the biological function of oxidation products in the healthy plants has not been still proved ${ }^{3}$. Although peroxidized unsaturated fatty acids have been suggested as precursors in the formation of ethylene, no enzymic mechanism was found ${ }^{7)}$.

On the other hand, plant tissues contain enzyme which is responsible for the cleavage of the fatty acid hydroperoxides to form carbonyl fragments. This enzyme cleaved the isomeric 9- and 13-hydroperoxydienes derived from both linoleic and linolenic acids, but did not attack a mixture of 9- and 10-hydroperoxymonoenoic derivatives of oleic acid ${ }^{12}$.

The purpose of this investigation is to determine if the hydroperoxide cleaving enzyme plays a role for the prevention of cell damage caused by hydroperoxides produced in CMV-infected cowpea and cucumber leaves.

\section{Materials and Methods}

Test Plant. Cowpea(Vigna sinensis Endl. var. sesquipedalis, cultivar Kurodane

* Supported in part by Grant from the Ministry of Education, Science and Culture of Japan (No,366019).

** Faculty of Agriculture, Tohoku University, Sendai 980, Japan 東北大学農学部 
sanjyaku) and cucumber plants (Cucumis sativus L. cultivar Best Green) were grown in a greenhouse at about 25-28 $\mathrm{C}$ under natural light condition. Virus : The yellow strain of CMV purified according to the method of Scott ${ }^{14)}$ was used for inoculating cowpea and cucumber leaves.

Inoculation. The upper surface of a primary cowpea leaf was inoculated with CMV by rubbing with carborundum, while the opposite leaf was rubbed with a phosphate buffer $(0.1 \mathrm{M}, \mathrm{pH} 7.0)$ to serve as a control. In cucumber, about 18 days after sowing, when the second true leaves began to appear, the first true leaves were inoculated by the rubbing method. Sampling : Samples for measurement of enzyme activity and malonaldehyde content were harvested at various times after inoculation.

Tissue extraction. The grinding medium contained $0.25 \mathrm{M}$ sucrose, $0.1 \mathrm{M} \mathrm{N}$ 2-hydroxyethylpiperazine-N-ethanesulfonic acid (HEPES) buffer, $\mathrm{pH} 7.6,0.5 \%$ bovine serum albumin (BSA), $1 \mathrm{mM}$ EDTA and $1 \mathrm{mM} \mathrm{MgCl}_{2}$. The leaves were homogenized in a blender and the homogenate was then filtered through several layers of gauze and centrifuged at the gravity shown in Table 1 . The pellets obtained after each centrifugation were resuspended in the extraction buffer and were used as crude enzymes.

Identification of membrane fractions by using enzyme markers. Identification of 4 fractions separated by differential centrifugation was carried out by the distribution of marker enzymes. Marker enzymes used in these experiments were catalase (microbody), triose-phosphate isomerase(plastide), cytochrome oxidase(mitochondria), ATPase (plasma membrane) and $\mathrm{NADH}$-cytochrome $\mathrm{c}$ reductase (endoplasmic reticulum).

Enzyme assay. Hydroperoxide cleaving enzyme was assayed by the disappearance of 9- and 13-hydroperoxycatadienoic acids in a recording spectrophotometer at $234 \mathrm{~nm}$. The reaction mixture contained $0.3 \mathrm{ml}$ of the crude enzyme preparation, $0.3 \mathrm{ml}$ of the hydroperoxide preparation and $2.4 \mathrm{ml}$ of $0.1 \mathrm{M}$ phosphate buffer $(\mathrm{pH}$ 6.2 or 6.8 ). The hydroperoxides were prepared from linoleic acid by the method of Hamburg \& Summelsson ${ }^{5}$ and soybean lipoxygenase was used throughout this study. If the enzyme preparation was heated to $100 \mathrm{C}$ for $1 \mathrm{~min}$ and incubated with the substrate, no decrease in absorbance at $234 \mathrm{~nm}$ was observed. Catalase was determined by the method of Luck ${ }^{10)}$. Triose-phosphate isomerase was coupled with glycerol phosphate dehydrogenase and followed by the oxidation of $\mathrm{NADH}^{16)}$. Cytochrome oxidase was determined by the method of Tolbert et al. ${ }^{15)}$. ATPase was assayed at $37 \mathrm{C}$ with and without $\mathrm{K}^{+}$ions. The reaction mixture contained $3 \mathrm{mM}$ ATP, $0.1 \mathrm{M}$ HEPES buffer, $\mathrm{pH} 6.5,3 \mathrm{mM} \mathrm{MgSO}_{4}$ and $50 \mathrm{mM} \mathrm{KCl}$ where appropriate. Inosine diphosphatase (IDPase) was assayed before and after 3 days storage at 0-2 $\mathrm{C}$, by the method of Ray et al. ${ }^{13)}$. With both ATPase and IDPase the final volume of the reaction mixture was $3 \mathrm{ml}$, excluding $0.2 \mathrm{ml}$ of $30 \%$ TCA used to stop the reaction after $30 \mathrm{~min}$. Inorganic $P$ was measured from a $0.5 \mathrm{ml}$ sample, containing less than $1 \mu \mathrm{mol}$ of ATP or IDP, by the method of Parvin \& Smith ${ }^{11)}$ and the activity was expressed, after the removal of enzyme blanks, as $\mu \mathrm{g}$ of phosphate. NADHcytochrome c reductase was determined by the method of Donaldson et al. ${ }^{2}$ at a $\mathrm{pH}$ of 7.0 and in the presence of Antimycin A. Malonaldehyde : Malonaldehyde content was measured as described previously6).

Protein. Protein content was determined by the method of Lowry et al. ${ }^{9}$.

\section{Results}


Table 1. Location of enzymes in fractions obtained by differential centrifugation (Cowpea leaves)

\begin{tabular}{|c|c|c|c|c|}
\hline $\begin{array}{l}\text { Enzyme location } \\
\text { fraction }\end{array}$ & $\left|\begin{array}{c}4000 \mathrm{~g}, 10 \\
\text { min pellet } \\
\% \text { activity }\end{array}\right|$ & $\begin{array}{l}9000 g, 20 \\
\text { min pellet } \\
\% \text { activity }\end{array}$ & $\left|\begin{array}{l}35000 g, 30 \\
\text { min pellet } \\
\% \text { activity }\end{array}\right|$ & $\begin{array}{l}105000 g, 60 \\
\text { min pellet } \\
\% \text { activity }\end{array}$ \\
\hline $\begin{array}{l}\text { Hydroperoxide } \\
\text { cleavage }\end{array}$ & 12 & 12 & 41 & 18 \\
\hline Catalase & 28 & 12 & 1 & 0 \\
\hline $\begin{array}{c}\text { Triose phosphate } \\
\text { isomerase }\end{array}$ & 16 & 9 & 0 & 0 \\
\hline $\begin{array}{l}\text { Cytochrome } \\
\text { oxidase }\end{array}$ & 18 & 32 & 10 & 0 \\
\hline ATPase with $\mathrm{K}^{+}$ & 5 & 10 & 26 & 10 \\
\hline $\begin{array}{l}\text { IDPase } \\
\quad \text { after } 3 \text { days }\end{array}$ & 11 & 24 & 16 & 16 \\
\hline $\begin{array}{c}\text { NADH-cy tochrome } \\
\text { c reductase }\end{array}$ & 0 & 3 & 11 & 32 \\
\hline
\end{tabular}

Cowpea leaves homogenate was centrifuged at the stated $g$ and the pellet obtained after each centrifugation was resuspended in the extraction buffer. Activity refers to $\%$ in initial homogenate.

Table 2. Location of enzymes in fractions obtained by differential centrifugation (Cucumber leaves)

\begin{tabular}{l|c|c|c|c}
\hline $\begin{array}{c}\text { Enzyme location } \\
\text { fraction }\end{array}$ & $\begin{array}{c}4000 \mathrm{~g}, 10 \\
\text { min pellet } \\
\% \text { activity }\end{array}$ & $\begin{array}{c}9000 \mathrm{~g}, 20 \\
\text { min pellet }\end{array}$ & $\begin{array}{l}35000 \mathrm{~g}, 30 \\
\text { min pellet }\end{array}$ & $\begin{array}{c}105000 \mathrm{~g}, 60 \\
\text { min pellet } \\
\% \text { activity }\end{array}$ \\
\hline $\begin{array}{c}\text { Hydroperoxide } \\
\text { cleavage }\end{array}$ & 18 & 14 & 30 & 10 \\
$\begin{array}{c}\text { Catalase } \\
\text { Triose phosphate } \\
\text { isomerase }\end{array}$ & 3 & 12 & 6 & 1 \\
$\begin{array}{c}\text { Cytochrome } \\
\text { Oxidase }\end{array}$ & 21 & 24 & 9 & 0 \\
$\begin{array}{c}\text { ATPase with K } \\
\text { IDPase } \\
\text { after 3 days }\end{array}$ & 10 & 10 & 13 & 4 \\
$\begin{array}{c}\text { NADH-cytochrome } \\
\text { c reductase }\end{array}$ & 3 & 12 & 12 & 12 \\
\hline
\end{tabular}

Cucumber leaves homogenate was centrifuged at the stated $g$ and the pellet obtained after each centrifugation was resuspended in the extraction buffer. Activity refers to $\%$ in initial homogenate.

Table 3. Subcellular localization of hydroperoxide cleavage activity in cowpea primary leaves

\begin{tabular}{l|c|c|c}
\hline \multicolumn{1}{c}{$\begin{array}{c}\text { Subcellular } \\
\text { fraction }\end{array}$} & $\begin{array}{c}\text { Hydroperoxide } \\
\text { cleavage } \\
\text { activity* }\end{array}$ & $\begin{array}{l}\text { Protein } \\
\text { content** }\end{array}$ & $\begin{array}{c}\text { Specific } \\
\text { activity }\end{array}$ \\
\hline $35000 \mathrm{~g}, 30 \mathrm{~min}$ sup. & 0.05 & 1.4 & 0.04 \\
$\begin{array}{l}35000 \mathrm{~g}, 30 \mathrm{~min} \text { pellet } \\
\begin{array}{l}35000 \mathrm{~g} \text { (30min) sup. } \\
\text { from pellet after } \\
\text { suspension in 0.05\% } \\
\text { TritonX100 }\end{array}\end{array}$ & 0.41 & 0.6 & 0.68 \\
\hline
\end{tabular}

Enzyme activity was measured as $\triangle \mathrm{A}_{234 \mathrm{~nm}}$ by recording spectrophotometry. $* \mathrm{nmol} / \mathrm{min} / \mathrm{gr}$. $* * \mathrm{mg} / \mathrm{gr}$.
The results presented in Tables 1 and 2 show that the hydroperoxide cleavage activities in both cowpea and cucumber leaves, measured by loss of hydroperoxide $\left(\triangle A_{234 \mathrm{~nm}}\right)$, were concentrated in a particulate fraction sedementing at $35,000 \mathrm{~g}$. This particulate fraction contained a large amount of ATPase activity, and the activities increased in the presence of $\mathrm{KCl}$. These results, therefore, showed that the majority of cleavage activities was localized mainly in the plasma membranerich fraction lighter than mitochondria. Little activity was associated with endoplasmic reticulum, mitochondria and microbody fractions. The particulate activity could readily be solubilized by resuspending in $0.05 \%$ aqueous Triton $\mathrm{X}-100$. As indicated in Table 3 , recentrifugation of this mixture at $35,000 \mathrm{~g}$ for $30 \mathrm{~min}$ left almost all the activities in the supernatant. It was indicated that this enzyme was firmly bound to plasma membrane.

The $\mathrm{pH}$ optima for the hydroperoxide cleaving enzymes from cowpea and cucumber leaves were 6.2 and 6.8 , respectively.

\section{Changes of enzyme activity during infection}

Experiments were conducted to determine if the enzyme activity was altered during infection. The results are shown in Figures 1 and 2. After inoculation, the enzyme activity in cowpea increased rapidly during the first $12 \mathrm{hr}$ and then more gradually for the following $12 \mathrm{hr}$. After 24 $\mathrm{hr}$, the activity began to decrease and finally the level of enzyme activity remained below that of the control value. In this experimental condition, the necrotic lesion appeared about $18 \mathrm{hr}$ after 


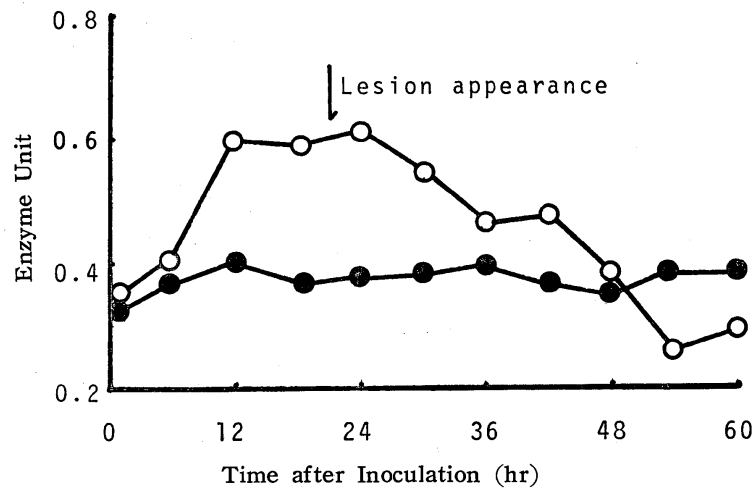

Fig. 1 Changes in hydroperoxide cleaving enzyme activity of CMV-infected cowpea leaves. Enzyme unit refers to nmol substrate reacted $/ \mathrm{min} / \mathrm{gr} \mathrm{fr}$. wt of tissue.

: Healthy leaves, $\bigcirc$ : Infected leaves.

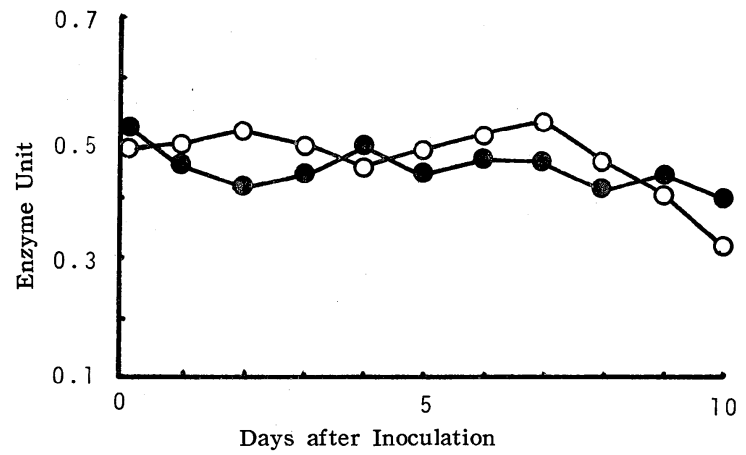

Fig. 2 Changes in hydroperoxide cleaving enzyme activity of CMV-infected cucumber leaves. Enzyme unit refers to nmol substrate reacted $/ \mathrm{min} / \mathrm{gr} \mathrm{fr}$. wt of tissue.

: Healthy leaves, $O$ : Infected leaves.

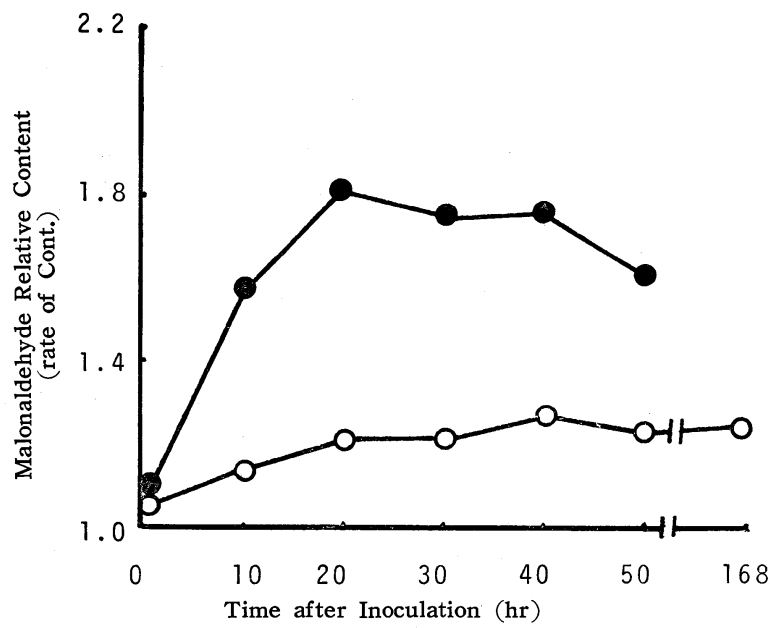

Fig. 3 Malonaldehyde production in CMV-infected cowpea and cucumber leaves.

: Cowpea leaves, $\bigcirc$ : Cucumber leaves. inoculation. In the case of cucumber leaves, however, the hydroperoxide cleavage activity. did not produce any alteration over a period of 10 days after inoculation. The mosaic symptom on the inoculated first true leaf appeared about 7 days after inoculation.

\section{Changes of malonaldehyde content in infected leaves}

The malonaldehyde contents of cowpea and cucumber leaves infected with CMV were determined by thiobarbituric acid (TBA) test ${ }^{1)}$. The TBA test is one of the common method used for detecting oxidation of lipids. This test is simple to conduct and is also highly sensitive. The TBA test is, in general, the reaction between TBA and some aldehydes contained in the so called secondary products formed from lipid peroxides. There are two absorption maxima associated with TBA test, one at ca. $450 \mathrm{~nm}$ and the other at $532 \mathrm{~nm}$. The latter is apparently specific for malonaldehyde and products which will derive malonaldehyde during the test.

Figure 3 showed changes in malonaldehyde content as a function of infection times. The amount of malonaldehyde in inoculated cowpea leaves certainly increased for 8-15 $\mathrm{hr}$ after inoculation and it decreased gradually as lesion appeared.

However, the amount of malonaldehyde in infected cucumber leaves did not conspicuously change throughout this study. The leak of malonaldehyde production in CMV. infected leaves indicated that a certain antioxidative system existed in cucumber leaf tissue.

\section{Discussion}

Plant tissues contain enzymes which, on physical distruption of the tissue, cause a sequence of 
lipid-degrading reactions. The first two enzymes in this sequence are lipolytic acylhydrolase and lipoxygenase. Recently, an enzymic sequence has been proposed for the formation of carbonyl fragments from linoleic and linolenic acids in extracts of various plant tissues ${ }^{4}$. The enzyme responsible for the cleavage of fatty acid hydroperoxides to form carbonyl fragments, including volatile aldehydes, traumatic acid and others, is believed to be the third in the sequence of lipid-degrading enzymes ${ }^{16)}$. Hydroperoxide cleaving enzymes from cowpea and cucumber leaves were mainly located in $35,000 \mathrm{~g}$ pellet (plasma membrane-rich fraction). This pellet contained high ATPase activity. Little enzyme activity was located in endoplasmic reticulum, mitochondria and microbody fractions.

Hydroperoxide cleavage activity in CMV-infected cowpea leaves increased until about $24 \mathrm{hr}$ after inoculation. It was considered that the locations showing activation of enzymes differed before and after the appearance of necrotic lesions. Before the appearance of lesions, the enzyme activity increased mainly in CMV-invaded cells. This increase of enzyme activity may occur for the degradation of cytotoxic hydroperoxides produced rapidly by infection.

But, the degradation was far from perfect. On the other hand, after hypersensitive death of virus-invaded cells, the increase of enzyme activity may occur in uninfected tissues surrounding the necrotic lesions. It was thought that the activation of this enzyme in adjacent healthy tissues resulted in a marked production of ethylene and wound hormone traumatic acid previously reported ${ }^{7}$.

In cucumber leaves, in spite of the existence of the lipid-degrading system, the hydroperoxide cleaving enzyme was not activated significantly by infection and malonaldehyde was present only in small quantities in infected leaves. The failure of the lipid peroxidation in infected cells may result from certain antioxidative actions. It was thought that active multiplication of virus in systemic host cucumber leaves was supported by the presence of some antioxidation system in cells.

The writer is indebted to Professor Susumu Yamanaka of Tohoku University for his valuable advice.

\section{Literature cited}

1. Dahle, L. K., Hill, E. G. and Halman, R. T. (1962). Arch. Biochem. Biophys. 98:253-261.

2. Donaldson, R. P., Tolbert, N. E. and Schnarrenberger, C. (1972). Ibid. $152: 199$.

3. Esselman, W. T. and Clagett, C. O. (1974). J. Lipid Res. $15: 173-178$.

4. Galliard, T., Phillips, D. R. and Reynolds, J. (1976). Biochim. Biophys. Acta $441: 181$.

5. Hamburg, M. and Summelsson, B. (1962). J. Biol. Chem. $242: 5329$.

6. Kato, S. and Misawa, T. (1976). Ann. Phytopath. Soc. Japan $42: 472-480$.

7. Kato ,S. (1977). Ibid. $43: 587-589$.

8. Kato, S. (1977). Tohoku J. Agr. Res. $28: 1-7$.

9. Lowry, O. H., Rosebrough, N. J., Farr, A. L. and Randall, R. J. (1951). J. Biol. Chem. $193: 265-275$.

10. Luck, H. (1965). In Methods of Enzymatic Analysis (Bergmeyer, H. V. ed.). Acad. Press N. Y. pp 885.

11. Parvin, R. and Smith, R. A. (1969). Anal. Biochem. $27: 65$.

12. Phillips, D. P. and Galliard, T. (1978). Phytochemistry $17: 355-358$.

13. Ray, P. M., Shininger, T. L. and Ray, M. M. (1969). Proc. Natl. Acad. Sci. U. S. $64: 605$.

14. Scott, H. (1963). Virology $20: 103-106$.

15. Tolbert, N. E., Oeser, A., Kisaki, T., Hageman, R. H. and Yamazaki, R. K. (1968). J. Biol. Chem. $243: 5179$.

16. Wardale, D. A., Lambert, E. A. and Galliard, T. (1978). Phytochemistry $17: 205-212$. 
和 文 摘 要

CMVに感染したササゲおよびキュウリ葉内に

生成される脂質過酸化物の酵素的分解

\section{加藤 盛}

ササゲとキュウリ葉における脂質過酸 化物 分解酵素の細胞内分布と CMV に感染した場合の酵素活性の 変化について検討した。両植物葉では本酯素活性の大部分は原形質膜に分布しており，他に小胞体やミトコ ンドリア，マイクロボデー分画にも多少の分布が認められた。CMVの局部感染宿主であるササゲではCMV 感染後12時間以内に本酵素の活性が急速に增大し，また，過酸化反応の指標として使用したマロンアルデヒ ドの量も著しく増大した。しかし，局部病斑出現以後は両者共漸減の傾向を示した。一方，てれと対照的に 全身感染宿主であるキュウリの場合は, 感染後10日を経ても酵素活性やマロンアルデヒド含量に殆んど変化 はみられなかった。 